\title{
WPS3310
}

\section{Bundling OF Services ANd Household Welfare in Developing Countries: The Case of Perú}

\author{
NOVEMBER 2003
}

Alberto ChONG, Jesko HentsChel, AND JAIME SAAVEDRA*

\begin{abstract}
Using panel data for Perú for the period 1994-2000, we find that when households receive two or more services jointly, the welfare increases of the household, as measured by changes in consumption, are larger than when services are provided separately of each other. Such increase appears to be more than proportional, as F-tests confirm on the coefficients of the corresponding regressors confirm. Thus, we find that bundling of services may help realize welfare effects.
\end{abstract}

JEL Classification: O1, O2

Key Words: Bundling, Expenditures, Public Services, Welfare, Panel Data

Word Count: 1,747

\footnotetext{
* Chong: Inter-American Development Bank; Hentschel: The World Bank, Latin America and Carribbean Region; Saavedra: The World Bank, Latin America and the Carribbean Region. We are grateful to Vajeera Dorabawila, Virgilio Galdo, and Pablo Suárez, for excellent research assistance. The views and opinions in this paper should not be attributed to the Inter-American Development Bank, the World Bank, or their corresponding executive directors. The standard disclaimer applies. Correspondence: Chong, Research Department, Stop W-0436, Inter-American Development Bank, 1300 New York Avenue, NW, Washington, DC 20577, USA. Tel. (202) 623-1536; Fax (202) 623-2481. E-mail: albertoch@iadb.org
} 


\section{INTRODUCTION}

A crucial policy question in developing countries is whether to provide basic social services individually or through an integrated approach in a bundled fashion. Today, most development agencies and Governments finance service provision through large sector programs, providing services to the beneficiary population on an individual basis, i.e. through separate water supply, electricity, or telecommunications projects. Such sector programs typically have little coordination between them. Similarly, even social or infrastructure fund projects, that offer a menu of different services to the beneficiary population, typically only finance one type of service for participating communities. Most of these fund projects follow a menu-approach with local populations choosing the type of service they consider most important for their development. But in most such projects, the beneficiary community will be excluded from renewed funding, at least until other, comparable communities have also benefited in a similar fashion.

Such singular provision of services could imply that two potential gains of bundling service provision are foregone: first, important savings could materialize due to economies of scale in the supply of bundled service delivery due to lower per unit connection costs of households. Second, and the subject of this study, bundling could also lead to higher household welfare improvements if the joint provision of services holds higher returns for the household than if services are provided individually. For example, clean water access could improve household's well-being somewhat but might do so substantially only if it were to come together with sanitation. Health risks might decline with water access only but the real benefits might only materialize if the services are provided together.

Empirical evidence on the impact of bundling public services on the welfare of the beneficiary population in developing countries is rare, largely due to lack of adequate data. We overcome this problem by using recent national household surveys and constructing a threeperiod panel for Peru. This country is one of a few that has panel availability for household surveys during a relatively extended period (1994-2000). Further, availability of panel data coincides with a period of relative stability (Saavedra and Chong, 1999) which can help identify service delivery welfare effects. The availability of household panel information for Peru has allowed some researchers to study dynamic patterns of consumption and income in the country. Glewwe and Hall (1998) use a limited panel data between 1986 and 1990 to study the decline in 
welfare of the most vulnerable during a macroeconomic shock ${ }^{1}$. Saavedra and Chong (1999) use a panel between 1991 and 1994 to study the patterns of the formal versus the informal sector in the country.

\section{Data AND Methodology}

We use three national-level household surveys for the years 1994, 1997 and 2000 and construct panels for the corresponding periods: (i) 1994-1997; (ii) 1997-2000; and (iii) 19942000. As a way of testing for robustness in our findings, we also look at three different increasingly restrictive panel sub-samples in each case. First, we focus on households that have the very same head of household between the periods considered (World Bank, 1999). Since the household head is typically the breadwinner in a developing country family, a change in the head can change the pattern of consumption radically. Second, we also focus on all the households that did not change size during the corresponding period of study. This, under the premise that changes in household size will affect the consumption pattern of the household (Lanjouw and Ravallion, 1995). Third, we focus on those households that both have the same head of household and the same household size during the corresponding period of the panel employed. This last comes as close as possible to a controlled experiment. In particular, the reduced form empirically estimated follows:

$$
\log \left(C_{h(x+t)} / C_{h(x)}\right)=\alpha+\varphi \ln \left(C_{h(x)}\right)+\beta S_{h(x)}+\chi P_{h(x)}+\mu_{h(x)}
$$

where the term in the left hand side is the rate of change in consumption per-capita between the period period $x$ and the period $(x+t)$ for a specific household $h^{2}$ Also, $S$ represents the variables that refer to characteristics of the household at the beginning of the measurement period. They include, the years of education of the head of the household, the age and gender of the head, mother tongue of the head, the number of members in the household, and whether the household belongs to a rural or urban area. $P$ includes our set of variables of interest, that is, access to basic services, in particular, (i) water, (ii) sewerage, (iii) electricity, and (iv) telephones, again at the beginning of the measurement period. While this is simple approach is relatively standard (Bisogno and Chong, 2001; Glewwe and Hall, 2000), the key advantage is

\footnotetext{
${ }^{1}$ The 1986 panel it is not representative at the national level, and only so for Lima, the capital.

${ }^{2} C_{h(x)}$ is the consumption level at the initial period $x$, and $C_{h(x+t)}$ is the consumption level at the end of the period, $(x$ $+t)$.
} 
that it helps minimize endogeneity problems as we only include exogenous variables as initial conditions at the beginning of the measurement period.

\section{RESUlts AND RobUSTNESS}

The findings of our analysis are presented in Table 1. Households that receive more than one service at the same time enjoy higher welfare, as measured by per-capita expenditures, compared to those households that do not. Having access to one public service only, regardless of which one service that is, does not yield a statistically significant increase in welfare in any of our three panel regressions in Table 1. However, having access to two or more services together, regardless of which combination of services this is, does yield higher welfare and appears to be proportionally higher than when the effect is measured separately. Indeed, we find important evidence of increasing returns to the number of services households command. This is shown in the size of the corresponding coefficients for one, two, and more services, and in the fact that resulting coefficients due to marginal service addition tend to be statistically significant as shown in the lower panel of Table 1. In fact, the marginal impact of adding one public service to the welfare of the household tends to be statistically significant at conventional levels, in two out of the three panels considered as corresponding F-tests show.

The above results are robust to changes in specification and, in particular, to potential variations due to changes in head and size of households. Both are critical to the dynamic consumption pattern of households (Lanjouw and Ravallion, 1995). Table 2 shows robustness regressions restricted to households that changed neither heads nor size between 1994 and 2000. We find that, regardless of the sub-sample employed, households that have access to more than one basic service are typically better off than those households that do not have such access. This is particularly clear in the case of households receiving three or more services, in the 1994-1997 panel, and to a large extent, in the 1997-2000 panel, too. Increasing returns appear to be also

present in most of these cases. F-tests on the coefficients of services provide support on the latter, particularly in the case of three services or more.

On the other hand, these findings can only be corroborated in the "same head" case using the 1994-2000 panel. Lack of data is likely the culprit as the number of observations drops from 601 in the full sample, to 123 (same size) and 109 (same size and head). Lack of sufficient information in the different panel datasets also appears to be the reason why we obtain no 
systematic pattern when testing the sequence of specific service combinations (say, water and electricity, water and telephone, electricity and telephone, and so on). ${ }^{3}$

\section{Conclusions}

In this note we find important evidence that bundling of infrastructure services matters for households. When households receive two or more services jointly, the welfare increases are larger than when services are provided each one separately. The additional, positive impact of one new basic service increases with the total number of services available. Such increase appears to be more than proportional, as F-tests on the coefficients of the corresponding regressors confirm. Therefore, the joint provision of services helps realize welfare effects. This logic appears to be valid, at least, for the four services considered in this study, namely, sanitation, electricity, water, and telephone services. Lack of data power does not allow us to examine the most beneficial sequence of service provision which would constitute an important area for further research.

3 The above results (suggesting the existence of welfare effects from service bundling) are not due a composition effect of service provision. If all services show constant returns but households gain access to services in a particular order, then increasing returns could simply be the result of (typically) earlier provided services having lower returns than (typically) later provided services. However, we find no statistically significant difference in estimated service parameters when we include (i) all four services separately, or (ii) all possible combinations of two services. 


\section{REFERENCES}

Bisogno, Marcelo and Alberto Chong (2001) "Foreign Aid Targeting in Bosnia and Herzegovina", European Economic Review, 45: 1020-1030.

Glewwe, Paul and Gillette Hall (1994) "Poverty, Inequality and Living Standards During Unorthodox Adjustment: The Case of Peru, 1985-1990" Economic Development and Cultural Change, 42(4): 689-717.

Glewwe, Paul and Gillette Hall (1998), "Are Some Groups More Vulnerable to Macroeconomic Shocks than others? Hypotheses Tests Based on Panel Data from Peru". Journal of Development Economics, 56 (1): 181-206

Cuanto, (various years), "Peruvian Living Standard Measurement Surveys", 1994, 1997, 2000. Lima.

Lanjouw, Peter and Martin Ravallion (1995) "Poverty and Household Size, The Economic Journal, 105, 433: 1415-34

Saavedra, Jaime and Alberto Chong (1999) "Structural Reform, Institutions and Earnings: Evidence from the Formal and Informal Sectors in Urban Perú" Journal of Development Economics, 35, 4: 95-116.

World Bank (1999) “Poverty and Social Developments in Perú: 1994-1997”, Washington, DC. 


\section{TABLE 1}

Bundling of Services and Household Welfare in Peru 1994-1997-2000

\begin{tabular}{|c|c|c|c|}
\hline & $\begin{array}{c}(1) \\
1994-1997 \\
\end{array}$ & $\begin{array}{c}(2) \\
1997-2000 \\
\end{array}$ & $\begin{array}{c}(3) \\
1994-2000 \\
\end{array}$ \\
\hline Log of Per-Capita Consumption $C h(x)$ & $\begin{array}{c}-0.698 \\
(0.029)^{* * *}\end{array}$ & $\begin{array}{c}-0.540 \\
(0.028)^{* * *}\end{array}$ & $\begin{array}{c}-0.559 \\
(0.042)^{* * *}\end{array}$ \\
\hline Years of Education of Head of Household & $\begin{array}{c}0.028 \\
(0.004)^{* * *}\end{array}$ & $\begin{array}{c}0.028 \\
(0.003)^{* * *}\end{array}$ & $\begin{array}{c}0.025 \\
(0.006)^{* * *}\end{array}$ \\
\hline Mother Tongue of Head of Household & $\begin{array}{c}0.120 \\
(0.034)^{* * *}\end{array}$ & $\begin{array}{c}0.117 \\
(0.030)^{* * *}\end{array}$ & $\begin{array}{c}0.023 \\
(0.049)\end{array}$ \\
\hline Age of Head of Househould & $\begin{array}{c}0.006 \\
(0.001)^{* * *}\end{array}$ & $\begin{array}{c}0.006 \\
(0.001)^{* * *}\end{array}$ & $\begin{array}{c}0.009 \\
(0.002)^{* * *}\end{array}$ \\
\hline Gender of Head of Household $($ Male $=1)$ & $\begin{array}{c}-0.116 \\
(0.041)^{* * *}\end{array}$ & $\begin{array}{l}-0.003 \\
(0.034)\end{array}$ & $\begin{array}{c}-0.010 \\
(0.060)\end{array}$ \\
\hline Number of Members in Household & $\begin{array}{c}-0.037 \\
(0.007)^{* * *}\end{array}$ & $\begin{array}{c}-0.034 \\
(0.006)^{* * *}\end{array}$ & $\begin{array}{c}-0.023 \\
(0.011)^{* *}\end{array}$ \\
\hline Head of Household was Born in Current Area & $\begin{array}{l}-0.047 \\
(0.031)\end{array}$ & $\begin{array}{l}-0.024 \\
(0.024)\end{array}$ & $\begin{array}{c}0.000 \\
(0.044)\end{array}$ \\
\hline Percentage of Members of Household that Work & $\begin{array}{c}0.069 \\
(0.071)\end{array}$ & $\begin{array}{c}0.099 \\
(0.056)^{*}\end{array}$ & $\begin{array}{l}-0.078 \\
(0.108)\end{array}$ \\
\hline Urban & $\begin{array}{c}0.054 \\
(0.049)\end{array}$ & $\begin{array}{l}-0.016 \\
(0.038)\end{array}$ & $\begin{array}{c}0.159 \\
(0.071)^{* *}\end{array}$ \\
\hline Household Receives One Service & $\begin{array}{c}0.055 \\
(0.052)\end{array}$ & $\begin{array}{c}0.031 \\
(0.039)\end{array}$ & $\begin{array}{c}0.139 \\
(0.073)^{*}\end{array}$ \\
\hline Household Receives Two Services & $\begin{array}{c}0.161 \\
(0.056)^{* * *}\end{array}$ & $\begin{array}{c}0.157 \\
(0.044)^{* * *}\end{array}$ & $\begin{array}{c}0.186 \\
(0.180)^{* *}\end{array}$ \\
\hline Household Received Three Services & $\begin{array}{c}0.300 \\
(0.064)^{* * *}\end{array}$ & $\begin{array}{c}0.287 \\
(0.050)^{* * *}\end{array}$ & $\begin{array}{c}0.272 \\
(0.092)^{* * *}\end{array}$ \\
\hline Household Receives Four Services & $\begin{array}{c}0.434 \\
(0.081)^{* * *}\end{array}$ & $\begin{array}{c}0.488 \\
(0.063)^{* * *}\end{array}$ & $\begin{array}{c}0.430 \\
(0.119)^{* * *}\end{array}$ \\
\hline Constant & $\begin{array}{c}5.193 \\
(0.231)^{* * *}\end{array}$ & $\begin{array}{c}3.580 \\
(0.226)^{* * *}\end{array}$ & $\begin{array}{c}3.744 \\
(0.340)^{* * *}\end{array}$ \\
\hline $\begin{array}{l}\text { Observations } \\
\text { R-Squared }\end{array}$ & $\begin{array}{c}874 \\
0.44\end{array}$ & $\begin{array}{l}1767 \\
0.20\end{array}$ & $\begin{array}{c}601 \\
0.28\end{array}$ \\
\hline $\begin{array}{l}\text { Test of Coefficients of Services } \\
\text { Two Services }\end{array}$ & & & \\
\hline $\begin{array}{l}\text { F-Test } \\
\text { Probability }\end{array}$ & $\begin{array}{l}0.434 \\
0.510\end{array}$ & $\begin{array}{l}2.267 \\
0.132\end{array}$ & $\begin{array}{c}2.966 \\
0.085^{*}\end{array}$ \\
\hline Three Services & & & \\
\hline $\begin{array}{l}\text { F-Test } \\
\text { Probability }\end{array}$ & $\begin{array}{l}1.163 \\
0.281\end{array}$ & $\begin{array}{c}3.926 \\
0.047 * *\end{array}$ & $\begin{array}{c}3.175 \\
0.073^{*}\end{array}$ \\
\hline Four Services & & & \\
\hline $\begin{array}{l}\text { F-Test } \\
\text { Probability }\end{array}$ & $\begin{array}{l}1.681 \\
0.195\end{array}$ & $\begin{array}{c}6.693 \\
0.01 * * *\end{array}$ & $\begin{array}{c}3.937 \\
0.041 * *\end{array}$ \\
\hline
\end{tabular}

The dependent variable is the change in per-capita consumption at the household level. Standard errors in parentheses; *statistically significant at ten percent; ** statistically significant at five percent; *** statistically significant at one percent. Public services included are (i) piped water connection to the home for thirteen hours per day or more; (ii) access to electricity; (iii) access to telephone line at home; and (iv) access to sewerage services at home 



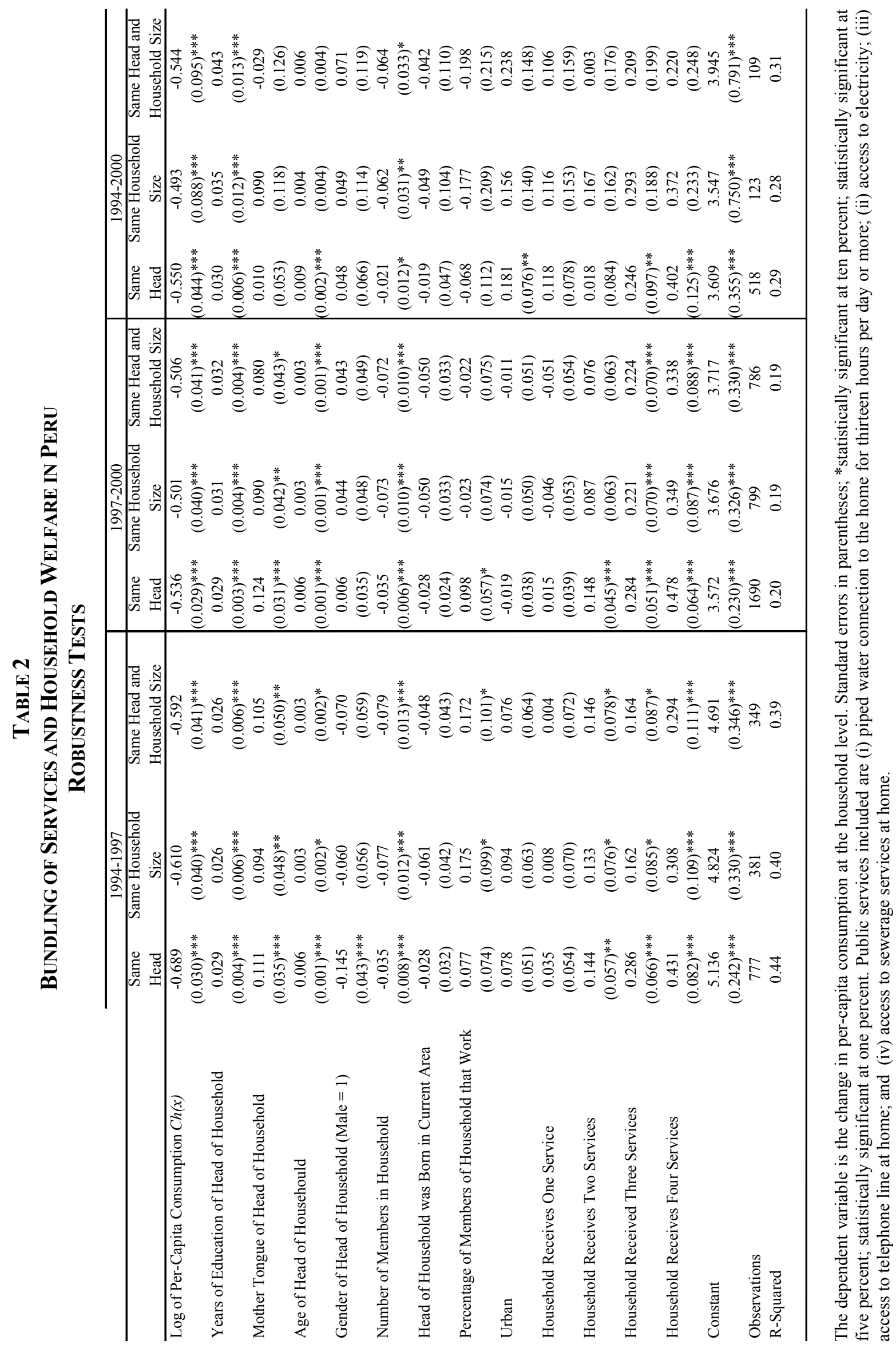

